\title{
OVERVIEW OF ECONOMICAL THEORETICAL CONCEPTS ASSOCIATED WITH THE ECONOMIC EFFICIENCY RESEARCH OF STATE FORESTS NATIONAL FOREST HOLDING
}

\author{
Przemysław Suchodolski, MSc ${ }^{1}$ \\ Faculty of Economic Sciences, Warsaw University of Life Sciences - SGGW
}

\begin{abstract}
The State Forests National Forest Holding is responsible for the management of forests owned by the State Treasury. The assessment of the economic effectiveness is difficult due to characteristic of Stare Forests, which is surrounded through legal restrictions. Economic efficiency in relation to National Forest Holding is understood as an activity aimed at achieving the goal by available resources. Evaluation of economic efficiency is based on technical, production and allocation efficiency. Economic theories, most suitable for the specification of National Forest Holding, focus around the New Institutional Economy. Economic concepts which solve sub-problems related to the research, refer to the monopolistic character of the entity and its basic function, that is self-financing.
\end{abstract}

Keywords: State Forest National Forest Holding, economic efficiency, monopoly, transaction costs JEL codes: D23, D42, D61, L73, Q23

\section{INTRODUCTION}

The basic activity of the State Forest Economy State Forests is, first of all, forest management, under which they can sell wood raw material. Wood raw material is the basic production material for many important areas of the Polish economy, e.g. construction, furniture industry, paper and cellulose industry. Thus, the supply and price of the raw material on the market is particularly important for these branches.

The Act of 28 September 1991 on forests specifies that the State Forests are an entity that operates on the principle of financial independence. This means that the State Forests must function in a way that ensures a source of income, that will be able to cover the total costs of operations and will ensure the possibility of further functioning and development.

The main source of revenues of the State Forests is the sale of wood, which is over $90 \%$ of total revenues (Lasy Państwowe, 2017). In 2016, the State Forests generated a net profit of PLN 404 million (Lasy Państwowe, 2017). The profit generated was allocated entirely for purposes related to the operation of State Forests. A relatively high net profit may indicate that the State Forests are a effective entity, however, the net profit to sales revenues amounted to $5 \%$ in 2016.

On a national scale, there is no enterprise with a similar business profile and similar cash flows. The specificity of the State Forests' business constitutes

${ }^{1}$ Corresponding author: Nowoursynowska 166, Warsaw, Poland, przemyslaw_suchodolski@sggw.pl, +48 669376763 
challenges for researchers in the form of identification all areas of activity. This is an interesting task that allows for multi-territorial monopolist analysis that works on behalf of the Treasury. The areas to be studied include the method of financing basic and investment activities, the organizational structure and the influence of external factors on the functioning of basic State Forest $t$ districts and the entity as a whole.

Economic efficiency is an action devoid of waste and aimed at achieving the best result within available resources and technologies (Lockwood, 2008). This term, however, should be interpreted as simultaneously achieving technological (technical and production) efficiency and allocation efficiency. All of mentioned types of efficiency also refer to the definition of financial efficiency of enterprises, which is a set degree of achieving the company's monetary goals, with particular privilege however maximizing its value, usually reflected by maximizing the benefits from equity involvement in assets, expressed in numbers absolute (profit, income, etc.), as well as relative values, or indicators (Kulawik, 2008).

The aim of this study is introduction to the subject of research into the economic efficiency of the State Forests and to review selected economic theories selected for the implementation of research on the above problem.

\section{THE CONCEPT OF EFFICIENCY}

Efficiency as an economic category is present in principle from the beginning of human history. Man has always struggled with the need to make the most favourable decisions for himself in conditions of limited resources. The progress of civilization caused that the efficiency category was assigned to many areas related to economic activity, e.g.: economic efficiency, effectiveness and equality, production efficiency, assets, operational and organizational efficiency, markets efficiency, management efficiency, global efficiency (Kożuń-Cieślak, 2013).
The universal application of the efficiency categories has caused great interest among economists. Over the years, it has gained a lot of explanation, depending on the application, which translated into many definitions of the concept.

The main categories of efficiency for which the definitions appear are:

- efficiency as a condition/element of achieving efficiency,

- efficiency as a criterion for effectiveness evaluation,

- effectiveness and efficiency as independent categories,

- efficiency $=$ productivity/performance,

- effectiveness understood as the allocation of resources in the Pareto sense (Kożuń-Cieślak, 2013). Samuelson and Nordhaus (1999) defined efficiency as using economic resources in the most effective way. In turn, Stoner, Freeman and Gilbert (2002) called effectiveness the measure of efficiency and effectiveness, the degree of achieving the set goals. Another definition of effectiveness was provided by Dudycz (2007), stating that it is, in the economic sense, a ratio of the value of the obtained effects to the effort of the factors used to obtain them. In the category of resource allocation in the Pareto sense, Kamerschen, McKenzie and Nardinelli (1991) gave ${ }^{2}$ a wide definition of efficiency, describing it as maximizing production resulting from proper allocation of resources, with given supply constraints (costs incurred by producers) and demand (consumer preferences).

The development of the concept of efficiency has resulted in its different types. Kożuń-Cieślak presented typology in a full way. It divided efficiency into two main categories, i.e. static and dynamic efficiency, which are considered in the short and long term. Within the mentioned categories, efficiency types such as: economic efficiency, technical efficiency, $\mathrm{X}$ effectiveness, innovative efficiency and adaptive efficiency have been specified. Technical efficiency has been further divided into: production and allocation. In turn, such types of allocation efficiency were as-

\footnotetext{
${ }^{2}$ It is impossible to reallocate so as to make any one individual or preference criterion better off without making at least one individual or preference criterion worse off (Pareto, 1890).
} 
signed to them in the following spheres: production, consumption and structure.

Economic efficiency requires the achievement of technical efficiency and allocation efficiency in the sphere of production, consumption and production structure. Technical efficiency is associated with technologically the most efficient use of resources. It is a necessary condition to achieve economic efficiency, but this does not mean that all technically effective solutions are also economically effective. Production efficiency is the economic expression of technical efficiency, which means that, from all technically efficient production methods, only production costs are minimally cost-effective. However, production efficiency does not guarantee that the produced goods maximize the satisfaction of buyers, who in the case of State Forests, are the buyer of wood raw material. Achieving such an entity requires allocation efficiency in the sphere of consumption and in the sphere of the production structure. The X-type effectiveness examines whether the company uses the resources at its disposal, such as work, land, capital, in the most cost-effective way - that is, whether a given level and set of effects is produced in the cheapest way possible (Kotarbiński, 1955) .

The allocation efficiency means that among all efficient production solutions only those that provide the greatest satisfaction on the consumption side have been selected. It is the allocation efficiency that is identified with economic efficiency, which means that the highest possible level of satisfaction has been achieved from the given resources.

Referring to efficiency in an organization, there are two dimensions that can be distinguished: operational and strategic. Effectiveness in the operational sense means implementing actions much better when doing what others do in the same industry, realizing the same concept of business operation. The strategic dimension of effectiveness is connected with the recommendation to act in a different way, thus realizing the unique concepts of business operation. In the situation of changing conditions of the environment, achieving natural goals of the company's operations, which include survival and development, requires efficiency both in the operational and strategic dimensions (Szymańska, 2010).

\section{THEORETICAL BACKGROUND}

The subject of assessment of management efficiency in forest areas has been repeatedly mentioned in research, both in Poland and abroad. The results of research carried out by Polish authors focused mainly on the methods of indicator analyses. An important contribution to the development of research on the effectiveness of forest management was presented by Marszałka (1974, 1975). A similar subject was also taken by Podgórski (1989), Szramka (1992, 1996) and Buraczewski and Wysocki (2000). The problem of the impact of natural and forest conditions on the efficiency of managing the organizational units of the State Forests was handled by Patalas (1987) and Kwiecień and Kocel (2006, 2010).

So far, no attempt to test the effectiveness of the State Forests as one enterprise has been made. Młynarski and Prędki (2016), using the DEA method, conducted a study of technical and financial efficiency on a given sample of forest divisions.

The use of non-parametric methods, and in particular DEA methods, to assess the effectiveness of forest management occurred in foreign studies. They mainly concerned forest management (Kao and Yang, 1991; Joro and Viitala, 1999; Bogatoft, Thorsen and Strange, 2003; Korkmaz, 2011), paper industry (Yin, 2000; Hailu and Veeman, 2001), harvesting timber (Lebel and Stuart, 1998; Hailu and Veeman, 2003) as well as the sawmill industry (Fotiou, 2000; Nyrud and Baardsen, 2003; Salehirad and Sowlati, 2005).

The characteristics of the DEA method assumes that the studied group of business entities applies similar technology. Two indicators $S 1$ and $S 2$ are calculated using the DEA methodology. If the first one equals one, then the object is characterized by a constant type of scale effect - it is also said that the unit is effective in scale. Otherwise, the unit is characterized by decreasing $(S 2<1)$ or increasing $(S 2=1)$ type of scale effect and in general is described as ineffective relative to the scale (Młynarski and Prędki, 2016).

The economic theory, whose features are part of the description of the State Forests, is New Institutional Economy. This theory in its assumptions fits into the model of State Forests, by capturing the main aspects that affect their functioning. 
The concept of the New Institutional Economy was established in the 1930s. The development of theory research took place in the 1970s and 1980s. The main representatives of this trend were: Ronald Coase, Olivier E. Williamson, Steven N.S. Cheung, Benjamin Klein, Robert G. Crawford, Armen Alchian, Kenneth J. Arrow, Harold Demsetz, Douglas North (Daniłowska, 2007). The new Institutional Economy is based on four main theories: transaction costs, property rights, agency and contract. The key concepts associated with the discussed concept include: institutions, organizations, transaction costs, contract and property rights.

The theory of transaction costs, derived from the New Institutional Economy, is of significant importance for the analysis and assessment of the effectiveness of the State Forests organization. Transaction costs are understood as the costs of obtaining product information, prices and transaction pages, costs of negotiating and concluding a contract, monitoring parties and enforcing obligations (Czyżewski and Grzelak, 2011). The State Forests, operating under free market conditions, have to bear these costs. The assumed assumption of treating State Forests as a typical economic entity operating under market conditions allows for referring this organization to the model of transnational corporations that aim to concentrate in order to limit or even eliminate transaction costs (Kraciuk, 2012). A similar model can be observed in the case of the State Forests, where the forest inspectorate can be compared to branch offices or branch offices of one large corporation, strongly dependent on its headquarters. The specification of transactional costs theory and corporate models with the organizational system of State Forests allows to assess the current state and present forms of solutions that would improve the organizational performance of the entity.

The new Institutional Economy described above is the main theory on which the study of the economic efficiency of the State Forests is based. However, the implementation of a comprehensive study requires reference to other theories whose task will be to help clarify the so-called sub-problems. These include, among others, identifying the organizational model of the State Forests, identifying the system of redistribution of financial resources. For this purpose, addi- tional theories have been indicated, which will refer only to individual aspects of economic effectiveness research. Among the auxiliary theories are located: Theory of financing sources hierarchy, Theories of monopoly.

The theory of the hierarchy of financing sources is based on the concept of information asymmetry and the occurrence of transaction costs that are derived directly from the New Institutional Economy. What is more, there is a distinction between own funds, i.e. generated by the company in the course of its current activity and foreign, acquired from the outside, in the form of debt or share capital (Frydenberg, 2011). In the theory of the hierarchy of financing sources, enterprises raise funds for operations and investments in a specific sequence. The source of financing first selected are own funds, then debt and share/share capital (Myers, 1984).

Theories of monopoly, whose assumptions refer to the activities of the State Forests, originate from the Austrian school. The assumptions of this school are similar to those from the New Institutional Economy. One can include methodological individualism and methodological subjectivism.

The phenomena of methodological individualism and methodological subjectivism are related to explaining consumer behaviour in categories that distinguish preferences, knowledge and expectations of individual individuals. In the case of State Forests, consumers should be understood as buyers of wood, whose presence cannot be ignored.

In the Austrian school, three main theories of monopoly can be distinguished: Ludwig von Mises, Israel Kirzner, Murray N. Rothbard.

The theory of von Mises's monopoly assumes that 'the whole supply is controlled by one producer or a group of working producers'. Mises assumed that monopolistic prices would arise if the demand for the product was inflexible and thus 'the monopoly price would be able to replace the competitive one'. 'The characteristic feature of monopolistic prices is ignoring consumer wishes'. Mises points out that although the majority of monopolies and monopolistic prices can only arise as a result of state intervention, there are also circumstances that would allow them to emerge on the free market (Von Mises, 1963). 
Kirzner's monopoly theory indicates that the monopoly ceases to be sensitive to competitive activities. It also assumes that the tendency in the market covered by the monopoly of raw materials to establish a balance results in a higher price of the raw material and a higher price of the product obtained from this raw material. The important fact is that the term 'monopolist' refers to a producer who has a raw material monopoly, and is not necessarily the only producer of a given good. Such an entity is still subject to market processes because it is always possible to start competitive production. At the same time, when the supply of needed raw materials is limited by the exclusive ownership of the monopoly, the very possibility of competition is severely limited (Kirzner, 1973).

The theories of Von Mises and Kirzner have a common feature in the form of 'uniformity' of the raw material. This means that it is not possible to distinguish between existing resources. In practice, even the location of the raw material with identical characteristics distinguishes it from the others. Thus, it can be assumed that every entity with any resource is a monopolist. This simplification was noticed by Rothbard, who described the monopoly as a privilege granted by the state, reserving a given area of production for a specific group or individual. Giving a monopoly privilege makes the demand less flexible, because consumers cannot buy products from potential competitors of monopolists. In the free market, the price determined shows the voluntary decisions of consumers and producers. On the monopolistic market, a monopolistic price is set, as a result of which consumers lose, having fewer goods and paying a higher price (Rothbard, 1962).

\section{CONCLUSIONS}

The assessment of the economic effectiveness of the State Forest Economy State Forests requires work effort in many areas, which together form the overall result. The areas of technology, finance and management methods require great efficiency of decisionmakers and an extensive organizational structure.

In economic sciences, it is difficult to find an entity with similar characteristics, which means that it is necessary to rely on various theoretical concepts. In the case of assessing the economic efficiency of State Forests, the theoretical core is the New Institutional Economy, supported by other theories, characteristics of entity are the most complete.

The selection of appropriate economic theories and research methods is an important element of research on the economic effectiveness of the subject. The specificity of the State Forests requires a very accurate interpretation of the obtained research results in both the theoretical and the empirical part. The concept indicated in the text above serves the most faithful representation of the reality in which the State Forests operate.

\section{REFERENCES}

1. Bogatoft, P., Thorsen, B.J., Strange, N. (2003). Efficiency and merger gains in the Danish forestry exten $\neg$ sion service. Forest Science, 49 (4), pp. 585-595.

2. Buraczewski, A., Wysocki, F. (2000). Ocena sytuacji finansowej nadleśnictw za pomocą syntetycznego miernika rozwoju [Assessment of financial situation of forestry districts using a synthetic measure of development]. Sylwan, 144 (1), pp. 43-52.

3. Czyżewski, B., Grzelak, A. (2011). Teoretyczne i praktyczne uwarunkowania kosztów transakcyjnych na przykładzie przemysłu spożywczego w Polsce w latach 1992-2009 [Theoretical and practical determinants of transaction costs on the example of the food industry in Poland in 1992-2009]. Retrieved from: www.nta. ue.poznan.pl/upload/File/.../koszty-tran-aktual.docx.

4. Daniłowska, A. (2007). Poziom zróżnicowania oraz uwarunkowania kosztów transakcyjnych kredytów i pożyczek rolniczych [The level of differentiation and determinants of transaction costs of agricultural loans and credits]. Wydawnictwo SGGW, Warszawa.

5. Dudycz, T. (2007). Efektywność - rozważania nad istota i pomiarem [Efficiency - reflection on essence and measurement]. Prace Naukowe AE we Wrocławiu, 1060, p. 11.

6. Fotiou, S.I. (20000 Efficiency measurement and logistics - an application of DEA in Greek sawmills in logistics in the forest sector. In: Sjöström, K. (ed.) Logistics in the Forest Sector. Timber Logistics Club, Helsinki.

7. Frydenberg, S. (2011). Capital Structure Theories and Empirical Tests: an Overview. In: red. Baker, K.H., Gerald, S., Martin G.S. (eds.) Hoboken Capital Structu- 
re and Corporate Financing Decisions. John Wiley \& Sons, Hoboken, NJ.

8. Hailu, A., Veeman, T.S. (2001). Non-parametric productivity analysis with undesirable outputs: An ap $\neg$ plication to the canadian pulp and paper industry. American Journal of Agricultural Economics, 83 (3), pp. 605-616.

9. Hailu, A., Veeman, T.S. (2003). Comparative analysis of efficiency and productivity growth in Canadian regional boreal logging industries. Canadian Journal of Forest Research, 33 (9), pp. 1653-1660.

10. Joro, T., Viitala, E.-J. (1999). The efficiency of public forestry organizations: A comparison of different weight restriction approaches. IIASA Interim Report IR-99-059. Retrieved from: http://www.metla.fi/pp/ EJVi/ju-lkaisut.htm.

11. Kamerschen, D.R., McKenzie, R.B., Nardinelli, C. (1991). Ekonomia [Economy]. Fundacja Gospodarcza NSZZ „Solidarność”, Gdańsk.

12. Kao, C., Yang, Y.C. (1991). Measuring the efficiency of forest management. Forest Science, 37 (5), pp. 1239 -1252 .

13. Kirzner, I.M. (1973). Competition and Entrepreneurship. University of Chicago Press, Chicago.

14. Kocel, J. (2004). Metoda określania jednostkowych kosztów standardowych prac leśnych na podstawie grupowania nadleśnictw o zbliżonych warunkach przyrodniczo-leśnych [The method of determining unit costs of standard forestry works based on grouping of forest inspectorates with similar natural and forest conditions]. Leśne Prace Badawcze, 3, pp. 31-51.

15. Kocel, J., Kwiecień, R. (2010). Metoda określania syntetycznego wskaźnika efektów gospodarowania zasobami przyrodniczymi, ludzkimi i ekonomicznymi nadleśnictw [The method of determining the synthetic indicator of the effects of managing natural, human and economic resources of forest districts]. Leśne Prace Badawcze, 71 (1), pp. 91-104.

16. Korkmaz, M. (2011). Productivity changes of forest enterprises in Turkey: A non-parametric Malmquist approach, African Journal of Agricultural Research, 6 (28), pp. 6189-6196.

17. Kotarbiński, T. (1955). Traktat o dobrej robocie [A good work treaty]. Ossolineum, Łódź.

18. Kozuń-Cieślak, G. (2013). Efektywność - rozważania nad istotą i typologia [Efficiency - reflection on essence and typology]. Kwartalnik Kolegium Ekonomiczno-Społecznego, Studia i Prace, 4, pp. 13-42.

19. Kraciuk, J. (2012). Transakcje pozarynkowe w świetle teorii kosztów transakcyjnych [Non-market transac- tions in light of the theory of transaction costs]. Roczniki Naukowe SERiA, 14 (1), pp. 256-259.

20. Kulawik, J. (ed.) (2008). Analiza efektywności ekonomicznej i finansowej przedsiębiorstw rolnych powstałych na bazie majątku WRSP [Analysis of economic and financial efficiency of agricultural enterprises created on the basis of WRSP assets]. IERiGŻ-PIB, Warszawa.

21. Kwiecień, R., Kocel, J. (2006). Metoda określania stopnia trudności gospodarowania nadleśnictw [A method to determine the level of difficulty of managing forest inspectorates]. Leśne Prace Badawcze, 2, pp. 51-71.

22. Lasy Państwowe (2017). Sprawozdanie finansowo-gospodarcze za rok 2016 [Financial and economic report for 2016]. Dyrekcja Generalna Lasów Państwowych, Warszawa.

23. Lebel, L.G., Stuart, W.B. (1998). Technical efficiency evaluation of logging contractors using a nonparametric model. Journal of Forest Engineering, 9 (2), pp. 15-24.

24. Lockwood, B. (2008). Pareto Efficiency. The New Palgrave Dictionary of Economics. 2nd ed. Palgrave Macmillan, Basingstoke.

25. Marszałek, T. (1974). Efektywność gospodarki leśnej [Effectiveness of forest management]. Sylwan, 10, pp. 8-16.

26. Marszałek, T. (1975). Efekty i efektywność [Effects and efficiency]. PWRiL, Warszawa.

27. Młynarski, W., Prędki, A. (2016). Ocena efektywności technicznej i finansowej wybranych nadleśnictw lasów państwowych za pomocą metody DEA [Assessment of technical and financial efficiency of selected forest districts of state forests using the DEA method]. Prace Naukowe Uniwersytetu Ekonomicznego we Wrocławiu, 446, pp. 126-143.

28. Myers, S.C. (1984). The Capital Structure Puzzle. Journal of Finance, 39 (3), pp. 575-592.

29. Nyrud, A., Baardsen, S. (2003). Production efficiency and productivity growth in Norwegian sawmilling. Forest Science, 49 (1), pp. 89-97.

30. Pareto, V. (1890). The new theories of economics. Journal of Political Economy, 5 (4), pp. 485-502.

31. Patalas, Z. (1987). Współczynniki trudności Wt dla nadleśnictw i OZLP [Wt difficulty factors for districts and OZLP]. Prace Instytutu Badawczego Leśnictwa, 663, pp. 41-51.

32. Podgórski, M. (1989). Efektywność produkcji leśnej „przy pniu” i „na pniu” w nadleśnictwach Lasów Państwowych [Effectiveness of forest production 'on trunk' 
and 'on trunk' in Forest State Forests]. Prace Komisji Nauk Rolniczych i Leśnych, 68, pp. 103-109.

33. Rothbard, M.N. (1962). Man, Economy, and State. Vol. II. D. Van Nostrand. Ludwig Von Mises Institute, Auburn, AL.

34. Rusielik, R. (2011). Efektywność techniczna funkcjonowania powszechnych towarzystw emerytalnych i jej zmiany - przykład zastosowania analizy granicznej [Technical efficiency of functioning of universal pension societies and its changes - an example of the application of border analysis]. Prace Naukowe Uniwersytetu Ekonomicznego we Wrocławiu, 167, p. 2.

35. Salehirad, N., Sowlati, T. (2005). Performance analysis of primary wood producers in British Columbia using data envelopment analysis. Canadian Journal of Forest Research, 35, pp. 285-294.

36. Samuelson, P.A., Nordhaus, W.D. (1999). Ekonomia [Economy]. PWN, Warszawa.

37. Stoner, J.A.F., Freeman, R.E., Gilbert, D.R. (1997). Kierowanie [Managing]. PWE, Warszawa.

38. Szramka, H. (1992). Wstępna analiza podstawowych determinantów ekonomicznej efektywności pracy w gospodarstwie leśnym [Initial analysis of the basic determinants of the economic efficiency of work in a forest holding]. Prace Komisji Nauk Rolniczych i Leśnych, 76, pp. 119-124.

39. Szramka, H. (1996). Próba oceny sytuacji gospodarczej nadleśnictw po wprowadzeniu nowych zasad gospodarki finansowej w Lasach Państwowych [An attempt to assess the economic situation of forestry inspectorates after the introduction of new rules of financial management in the State Forests]. Prace Komisji Nauk Rolniczych i Leśnych, 82, pp. 143-149.

40. Szymańska, E. (2010). Efektywność przedsiębiorstw - definiowanie i pomiar [Enterprise efficiency - defining and measuring]. Roczniki Nauk Rolniczych, G, 97 (2), pp. 152-164.

41. Ustawa z 28 września 1991 r. o lasach [Act of 28 September 1991 on forests]. Journal of Laws 1991 No 101 item 444.

42. Von Mises, L. (1963). Human Action. Yale University Press, New Haven, CT.

43. Yin, R. (2000). Alternative measurements of productive efficiency in the global bleached softwood pulp sector. Forest Science, 46 (4), pp. 558-569. 